\title{
The Effects of Global Interaction on Poverty in Developing Countries, 1991-2005
}

\author{
Jason K. Hall ${ }^{1}$ \\ Mid-America Christian University \\ jhall@macu.edu \\ Loretta E. Bass \\ University of Oklahoma
}

\begin{abstract}
While previous studies have examined the impact of globalization on a myriad of welfare outcomes in developing countries, the effect of cross-national exchanges on extreme poverty remains unexplored. Poverty has declined substantially during this most recent wave of globalization, suggesting that cross-border relations may be partially responsible. We test this proposition by estimating the impact of foreign direct investment (FDI), trade openness, and the presence of international non-governmental organizations (INGOs) on poverty, measured at both the \$1.25-a-day (extreme poverty) level, and the \$2.50-a-day (moderate poverty) level, net of domestic conditions. Using a sample of 114 developing countries over five waves of data collected from 1991 to 2005, results from random effects models show that FDI exhibits a positive relationship with poverty at the $\$ 1.25$ and $\$ 2.50$ levels, while trade openness demonstrates a negative relationship with both extreme and moderate poverty. Once domestic conditions are controlled, INGO participation fails to demonstrate a significant effect on poverty at either level. Among domestic variables, economic growth and fertility rate affect poverty at the \$1.25 level, while growth and domestic investment demonstrate an effect at the \$2.50 level. These findings confirm that global interaction by poor countries influences poverty reduction within these countries, but in different directions.
\end{abstract}

\footnotetext{
${ }^{1}$ The authors would like to thank Dr. Rob Clark for his assistance and review of this project.
} 
Over one billion people - around $25 \%$ of the world's population - live in extreme poverty, surviving on $\$ 1.25$ a day or less, with an additional two billion living in moderate poverty, on less than $\$ 2.50$ a day (Chen and Ravallion 2007). The great majority of these people live in lessdeveloped countries across the world. Individuals who face poverty at these levels have vastly decreased life chances relative to those with higher incomes, experiencing constant food insecurity, health problems, limited opportunities, and lowered life expectancies. Efforts to alleviate poverty have been a part of the philanthropic work of countries in the developed world and international organizations for decades, and a good deal of progress has been made. Globally, the percentage of the population living in extreme and moderate poverty has decreased since 1990 (Chen and Ravallion 2007; Ravallion, Chen, and Sangraula 2008), with particular gains in poverty reduction realized in many East and South Asian countries. However, these Asian successes have masked increased levels of poverty in many parts of Sub-Saharan Africa, Latin America, and the former Soviet countries of Eastern Europe (Sala-I-Martin 2006; Ravallion et al. 2008). Understanding this uneven success requires an examination of the processes - both global and domestic - that affect levels of poverty across countries. Currently, however, few studies examine these relationships at the global level (e.g., Sachs 2005; Collier 2007).

This study addresses this gap in development knowledge by examining extreme and moderate poverty levels by country over five waves covering the years 1991 to 2005 . Using economic and non-economic measures developed from international sources, this research analyzes global and domestic variables to determine the extent to which a country's experience of globalization affects the percentage of its population living in poverty at the $\$ 1.25$-a-day (i.e., extreme) and \$2.50-a-day (i.e., moderate) levels, net of domestic effects. Arguments from the neoclassical economic, dependency and world-systems, and world polity schools about the potential effects of foreign interactions will be tested in this analysis. This research addresses three questions: Does a country's level of interaction in the global environment via international economic and polity institutions affect the percentage of its population living in extreme poverty? Do the effects of global variables on poverty hold when controlling for domestic conditions within that country? Is there a difference in the effects of global interactions net of domestic conditions at the $\$ 1.25$-a-day and $\$ 2.50$-a-day levels?

\section{Review of Previous Literature}

\section{Poverty}

Reducing by one-half the world's population who live in extreme poverty over the period 1990 to 2015 is the first stated goal of the Millennium Declaration, signed by 152 heads of state from around the world in 2000 (United Nations 2007). Figure 1 portrays progress toward that goal by presenting the global trends in poverty since 1993 at the $\$ 1.25$ level. Though all regions have seen some level of reduction over this time period, an uneven distribution of poverty reduction across regions of the world is clearly evident. Within these regions, many countries have actually experienced significant increases in their levels of poverty (Sala-I-Martin 2006). Recent data on poverty levels suggest that these increases are becoming more commonplace due to the global economic slowdown and the disruptions in food availability and pricing that occurred in 2008 (United Nations 2009). 
Figure 1. Global \$1.25-per-day Poverty Trends by Region, 1993 - 2005

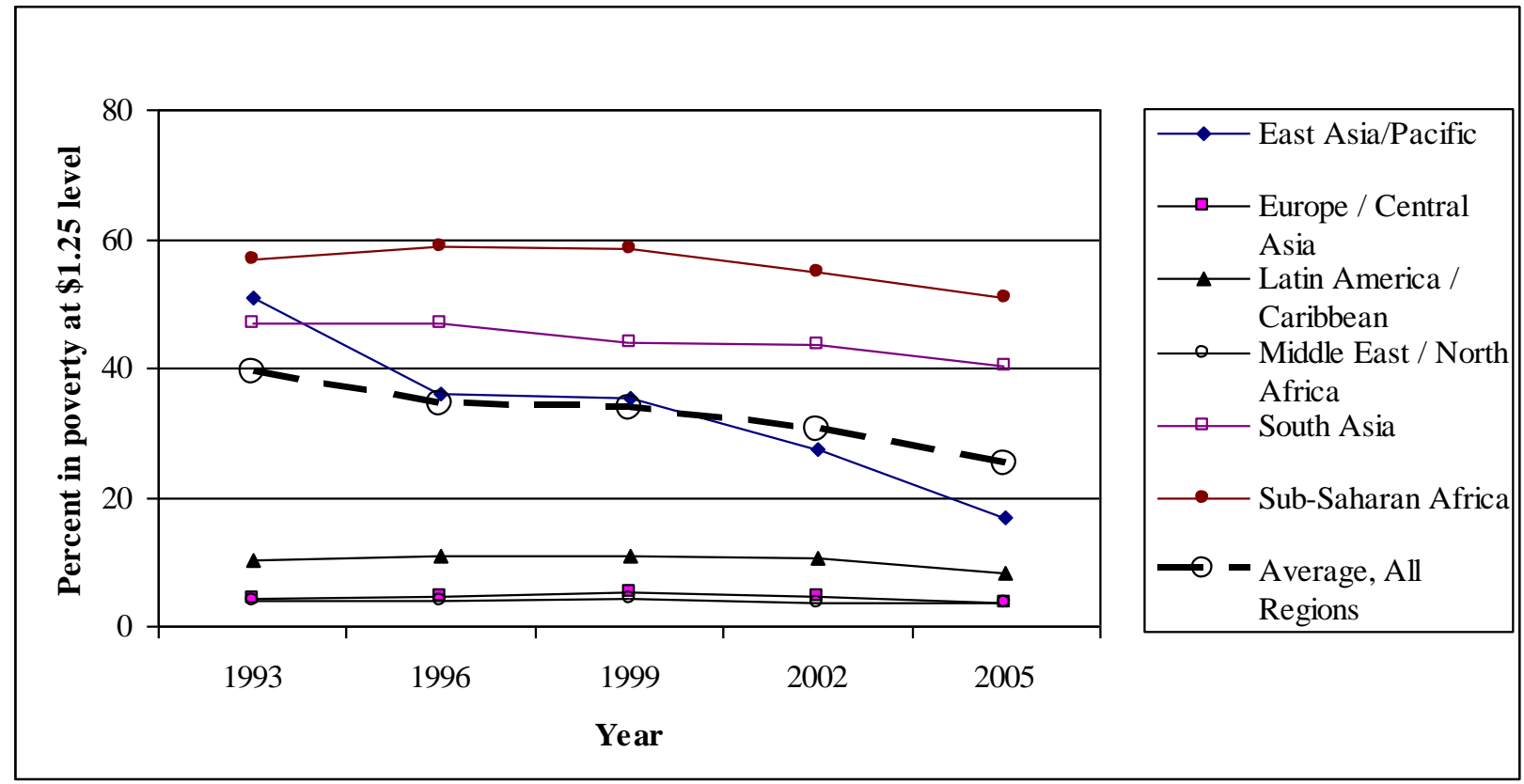

Source: Poverty levels are extracted from the World Bank Indicators database, 1991-2005 (World Bank 2010).

Figure 2. Global \$2.50-a-day Poverty Trends by Region, 1993 - 2005

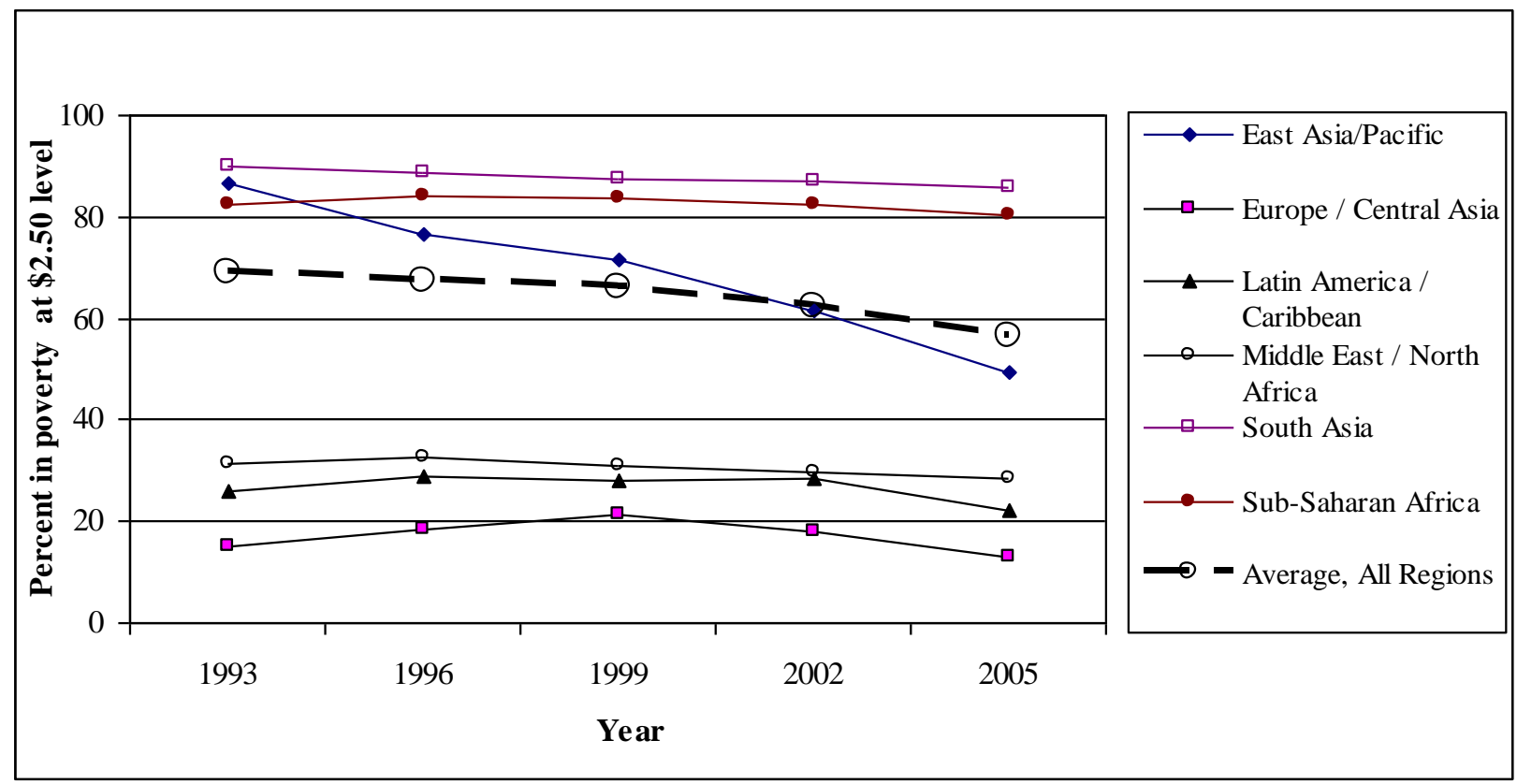

Source: Poverty levels are extracted from the World Bank Indicators database, 1991-2005 (World Bank 2010). 
While the Millennium Declaration specifically identifies extreme poverty reduction as the 2015 goal, Chen and Ravallion (2008) illustrate the usefulness of examining the \$1.25-a-day level of poverty as one threshold denoting extreme poverty in the poorest countries and the $\$ 2.50$-a-day level of poverty representing a typical poverty level among a broader range of developing countries. For comparison, trends in moderate poverty since 1993 are presented in Figure 2. While this figure demonstrates the same global downward trend as Figure 1, overall rates of moderate poverty are much higher than those of extreme poverty in every region of the world. Also of interest in Figure 2 are the trajectories of Sub-Saharan Africa and the emerging economies in Europe and Central Asia that show increases in moderate poverty through the third wave (i.e., 1999), followed by declines through the end of the period. The differences in prevalence and trajectory of poverty prevalence across these figures indicate that differences may exist with respect to the effects of global and domestic variables on poverty reduction at these distinct levels, necessitating separate analysis and comparison of the two.

Scholars have developed a number of ideas about why poverty exists at the levels and in the places it does. Among these, a key idea is the impact of interaction by developing countries in the global economic, political, and cultural systems. Proponents of greater global integration from the neoclassical school hold that increased participation in the global system brings economic benefits that are ultimately accompanied by welfare benefits for the general population (Sachs 2005). A competing view, developed by scholars in the dependency and world-systems schools, asserts that greater levels of globalization lead to negative economic and welfare outcomes as developing countries are exploited by those ahead of them on the development curve (Wallerstein 1974).

This study attempts to parse out the veracity of these opposing viewpoints (i.e., Sachs versus Wallerstein) with respect to the relationship between global integration and poverty reduction, net of domestic conditions that may influence poverty. The next sections review the scholarly and applied literature on what is known to influence poverty along three globalization areas of inquiry - foreign investment, trade openness, and international non-governmental organization involvement - and then considers the role of domestic factors in poverty reduction.

\section{Foreign Investment and Poverty}

Debates about the effects of foreign direct investment (FDI) in the developing world typically occur in contexts dealing with income inequality or economic development, but the principles discussed in these contexts can also be applied to poverty reduction. For those in the neoclassical school, the goal of every developing country should be the acquisition of as much foreign investment capital as possible (Firebaugh 1992). Because the source of investment money is not as important as its presence, it makes sense for countries to pursue foreign investment, as there are typically more funds available from foreign than domestic sources in developing countries. Researchers from this school have found positive effects of FDI on economic growth (Firebaugh 1992), health outcomes (Firebaugh and Beck 1994), education (Schofer and Meyer 2005), and domestic investment (de Soysa and Oneal 1999). These scholars acknowledge that growth in inequality may follow the growth brought by increased FDI, but this inequality is both acceptable and necessary as wages rise across the lower strata of the workforce (Firebaugh 2003). They argue that this increase in wages will eventually result in the elevation of incomes across most of the country. Whether this proves to be the case or not, the hypothesized increase 
in wages from an influx of FDI could serve to lift some of the population out of poverty, potentially linking FDI to poverty reduction.

Alternatively, scholars in the dependency school argue that gains identified by neoclassical scholars mask longer-term losses that often result in countries experiencing worse economic conditions than when they started (Kentor 1998). A number of studies from this perspective have found that FDI generates increased income inequality and slows economic growth (Bradshaw et al. 1993; Dixon and Boswell 1996; Kentor and Boswell 2003). Vijaya and Kaltani (2007) found that increased FDI flows have a negative impact on manufacturing wages in the developing world, particularly among female wage-earners, countering a central point of the neoclassical argument. These negative economic outcomes have also been linked to a number of negative health and welfare outcomes including food consumption (Wimberley and Bello 1992), quality of life (Bradshaw and Huang 1991), and infant mortality, child mortality, and calorie consumption among children (Bradshaw et al. 1993). Expanding on the dependency argument, world-systems scholars hold that these negative outcomes emerge as economies in the developing world participate in inherently unequal interactions with more developed countries (Wallerstein 1974). Through these relationships of exploitation and extraction, countries in the periphery of the world economy encounter greater difficulty in reducing poverty than those in the core or semi-periphery due to the inherent economic constraints of their relative isolation (Kim and Shin 2003). These perspectives lead to the prediction that increases in FDI inhibit poverty reduction as economic growth is stifled by the presence of foreign capital.

Few empirical studies examine the relationships between FDI and poverty, and the existing research has demonstrated mixed results (Sumner 2005). Dollar and Kraay (2001) find that increases in FDI inflows correspond with increases in income. This finding, however, may reflect only short-term gains that other studies have found to be negated over time (Kentor 1998). Most attempts to track this relationship find no relationship between FDI and different measures of poverty or income, including GDP growth (Carkovic and Levine 2002), income growth (Milanovic 2002), and poverty headcount (Agenor 2002). This study extends this line of research on the role of the relationship between FDI and poverty by examining a more recent dataset than these earlier studies and using panel data to allow for the examination of relationships both across countries and over time. In doing so, this study also tests the neo-classical argument (i.e., FDI would share a negative relationship with poverty) versus the dependency and worldsystems' argument (i.e., FDI would share a positive relationship with poverty).

\section{Trade Openness and Poverty}

Arguments about the effects of trade openness on poverty reduction are similar to the debates over FDI. Proponents of increased trade (i.e., again from the neoclassical school) argue that freer trade maximizes the size of potential markets, yielding greater opportunities to trade and encouraging greater productivity and entrepreneurship (Weede 2008). Sachs and Warner (1995), among others (Yanikkaya 2003; Wacziarg and Welch 2008), claim that expansion leads to greater economic growth and, as a result, a reduction in poverty. As economic growth is seen as a key to improved welfare outcomes (Firebaugh and Beck 1994; Jalles 2011), the expansion of trade is seen as a natural way to enhance growth and, by extension, human welfare.

Predictably, dependency scholars caution against countries throwing open their borders to trade with no protections, fearing that such openness will result in poorer countries being exploited by wealthier countries that are better able to dictate terms of trade to their advantage. 
The world-systems argument again emerges, expecting more open peripheral countries to be vulnerable to extraction of resources and exploitation because they do not have the connections or resources to develop industries that can compete with more developed countries in a global market.

While both sides assert the potential strength of effects in one direction or the other as a result of openness, research findings are mixed. Some studies have found little, if any significant relationship between openness and poverty (Dollar and Kraay 2004; Edwards et al. 2007). Ravallion (2006: 1388) investigated the relationship between openness and poverty reduction in case studies of China and Morocco, stating that his findings "cast doubt" that openness has either a positive or negative effect on poverty. Other case studies in the Philippines (Pernia and Quising 2003) and Brazil (Carneiro and Arbache 2003) offer further evidence that openness alone is insufficient for poverty reduction. This study extends this line of research by testing whether there is a trade openness effect on poverty alongside other competing global and domestic effects. As a result, this study therefore tests the neo-classical argument (i.e., trade openness would have a negative effect on poverty) versus the dependency argument (i.e., trade openness would have a positive effect on poverty).

\section{INGOs and Poverty}

The world polity perspective provides an alternative narrative to the neoclassical and dependency arguments. This school of thought credits the global rise in international non-governmental organizations (INGOs) and the subsequent development of a global civil society with many of the gains realized in development and welfare outcomes around the world. Beckfield (2003) notes substantial increases in INGO participation - generally measured as membership ties to INGOs- by every country in his study of INGO participation from 1960 to 2000. Highestgaining countries increased their memberships by as much as $400 \%$ over that span. More significantly, many countries at the bottom of the spectrum went from zero INGO ties in 1960 to over 200 in 2000. The coincidence of this proliferation with significant advances in human development outcomes has led scholars in the world polity school to conclude that the rise in INGOs is responsible for these positive development outcomes through the development and diffusion of world culture frames that challenge governments and individuals to adhere to global norms of citizenship (Boli and Thomas 1999). In addition to the development of these global ideas, INGOs can act as a "global third sector" beyond economics or politics that works outside of constraints placed by economies or governments (Salamon 1994) to influence human development and welfare outcomes by providing services (Chabbott 1999), funds (Ndegwa 1996), technology (Shirin 2000), and human capital (Chabbott 1999)

Research shows that INGOs have a positive effect on educational enrollment and persistence, health outcomes, environmental outcomes, women's rights and a reduction in the negative effects of overurbanization (Soros 2004). Jorgenson (2009) finds that the presence of environmentally-oriented INGOs is related to reduced industrial organic water pollution intensity. Examining factors shaping overurbanization in the developing world, Bradshaw and Schafer (2000) provide evidence that the increased presence of INGOs ameliorate the negative consequences associated with overurbanization, and further, that INGO expansion is positively related to economic growth and access to clean water. Finally, the world culture ideas espoused by these organizations encourage the growth of grass roots organizations within developing countries (Salamon 1994), help standardize trade and professional practices (Boli and Thomas 
1999), and lead to greater accountability of governments to their people and the international community (Bello 2001).

While research in the world polity framework has examined a number of welfare and development outcomes, a country's level of poverty represents an unexamined area that may be affected by INGO presence. As INGOs have been found to have a number of positive effects in areas related to economic development in poor countries and many of these organizations have emerged to deal with issues related to poverty, the presence of these organizations in a country may directly affect the extent of poverty present in that society. While not all INGOs deal with issues related to poverty and development, the world polity school asserts that their presence may influence poverty reduction through the distribution of world culture scripts that encourage the elimination of extreme and moderate poverty. Finally, as the majority of INGOs are devoted to issues like trade and commerce (Boli and Thomas 1997), the presence of these organizations may help create an economic climate in a country that lends itself to job creation and commerce, generating pathways for individuals to move out of poverty. Drawing on what is theoretically postulated by the world policy school, then, this study tests whether the presence of INGOs in a country is related to the poverty level.

\section{Domestic Conditions and Poverty}

Poverty levels in a country may be affected by factors both within and outside the country's borders. In addition to potential global influences on poverty, domestic conditions - such as economic growth, domestic investment, democratization, and population growth - shape economic and welfare outcomes in developing countries. Key among these domestic elements is economic growth. Neoclassical economics holds that, as economies grow, jobs are created, higher wages are paid, and greater market opportunities emerge, both within and outside of the country. Jalles (2011) finds that an increase in aggregate income is related to a decrease in poverty in the former Soviet states. In a study of the effects of changes in GDP per capita in the newly emerging economies of Central Asia and the Caucasus, Falkingham (2005) provides evidence of inequality and poverty rates declining as GDP per capita grows. Likewise, Jalilian and Kirkpatrick (2005) find a negative relationship between growth and poverty up to a certain threshold of development, which, in addition to a negative relationship among the poorest countries, suggests that more than one level of poverty should be examined. Beyond these economic outcomes, growth is also known to influence a number of welfare outcomes favorably, including: food consumption, infant survival, and life expectancy (Firebaugh and Beck 1994), one-to-five-year-old child survival (Brady, Kaya, and Beckfield 2007), and food security (Jenkins and Scanlan 2007). Based upon these prior studies, we expect that economic growth will demonstrate a negative relationship with poverty.

Similar to GDP, domestic investment is a salient factor to consider as being related to a country's poverty level. Domestic investment has been determined by scholars as one of, if not the most effective way, for a country to grow its economy (Firebaugh 1992). The application of domestic investment offers a double benefit for economic growth as it spurs indigenous development of business and industry and provides resources for investment as loans are repaid, markets are expanded, and incomes grow. In an examination of domestic investment in Africa, Anyanwu (2006) shows a clear relationship between high rates of domestic investment and higher levels of economic growth. Firebaugh (1992) and de Soysa and Oneal (1999) find similar relationships, demonstrating the efficacy of domestic investment in promoting growth. If 
economic growth affects poverty, then it is clear that domestic investment represents an important part of that growth.

Democracy is another domestic factor that may influence poverty, yet Kerbo's (2006) review of the development literature fails to find a consistent relationship between democracy and the presence of extreme poverty. While an overt relationship to poverty has not been identified, there are a number of studies investigating the relationship between democracy and inequality. As with examinations of poverty, the results of these studies are inconclusive. Bollen and Jackman (1985) find no relationship between inequality and democracy, while others (Simpson 1990; Crenshaw 1992) find clear evidence of a curvilinear relationship between the two using Bollen's (1980) Democracy Index. These studies show that inequality increases as a country's level of democracy increases, but that the relationship reverses once a threshold of democracy is achieved. Studies using a temporal measure of democracy find a similar curvilinear effect, with inequality declining as democracies reach the 20-year mark (Muller 1988). Therefore, it may be that nascent democracies have economic growth but not strong enough state institutions to ensure that this income is evenly distributed. Together, research in this area points to the need to include democracy as a salient factor that may affect the economy, and in turn, poverty.

Human capital, specifically in the form of education, is another domestic element that has the potential to affect the level of poverty within a country. An educated population is necessary for the adoption of new technologies and the attraction of businesses that require a more educated workforce. The United Nations has equated education with development in its discussion of the Millennium Development Goals (United Nations 2010). Barro (2001) finds that higher levels of school attainment are associated with greater economic growth. Education has also been linked to welfare outcomes such as reduced infant mortality and extended life expectancies (Brady et al. 2007). These findings point to the need to consider education as a domestic influence on the percentage of a country's population living in extreme or moderate poverty. The literature suggests that education will have a negative effect on the level of poverty.

The potential for population growth is another domestic element that may shape economic growth and poverty reduction. High population growth is related to lower economic growth (Barro 2001) and reductions in per capita income (Bloom and Sachs 1998). In studies directly linking poverty and population growth, scholars find fertility rates to be positively related to poverty levels in both developed (Abernethy 2002) and developing (Eastwood and Lipton 1999) countries. A high fertility rate is linked to higher inequality (Kentor 2001), greater levels of maternal morbidity and mortality (Goesling and Firebaugh 2004), and lower life expectancy and calorie consumption but higher infant mortality (Brady et al. 2007). Based upon this research, we expect that fertility will be positively associated with the percentage of a country's population living in poverty, whether measuring extreme or moderate levels, in the current analysis.

Each of these domestic elements has demonstrated effects on welfare outcomes. While other internal conditions play key roles in shaping the ability of a population to move out of poverty, we agree with Kentor (2001) that global processes affect these domestic conditions and anticipate that the global variables in this analysis will continue to demonstrate significant effects on poverty net of these domestic variables. Additionally, this examination of what is associated with poverty holds that we should control for regional variation and the temporal nature of the data. As Figures 1 and 2 clearly show, regions experience poverty and poverty reduction at different rates due to differential geography, access to trade route and ports, access to resources, 
and colonial histories. While these effects are not specifically controlled for in the analysis, controlling for regional variation captures many of these differences. Finally, as previous studies have demonstrated that change over time matters when examining poverty (Muller 1988; Simpson 1990: Crenshaw 1992;), we include a control variable to account for this variation.

\section{Statement of Research Problem}

This study seeks to examine the presence and persistence of extreme and moderate poverty by investigating relationships between both global and domestic variables and poverty scores at the $\$ 1.25$ and $\$ 2.50$-a-day levels, respectively, to determine the extent that these macro-level variables affect the percentage of a country's population that lives in poverty. To this end, three questions are addressed. First, does a country's level of interaction in the global environment via international economic and polity institutions affect the percentage of its population living in extreme poverty? Next, do the effects of global variables on poverty hold when controlled for domestic conditions within that country? Finally, is there a difference in the effects of global variables net of domestic conditions at the \$1.25-a-day and \$2.50-a-day levels?

This study anticipates that all of the globalization variables will demonstrate significant relationships with poverty at both levels. Specifically, and agreeing with dependency and worldsystems arguments, we expect FDI to have a positive relationship with poverty (i.e., higher levels of FDI penetration will be related to a higher percentage of the population living in poverty). Based on somewhat mixed findings in the scholarly literature and the limited effectiveness demonstrated by openness in previous studies, we predict that, agreeing with the neoclassical school, trade openness will have a slightly negative effect on poverty in the globalization models, but that this effect will not maintain significance net of domestic conditions. We hypothesize along with the world polity school in terms of the effect of INGO presence; we expect that countries with greater numbers of INGO ties will have a lower percentage of the population living in poverty over the period of the study compared with those with fewer INGO ties. Additionally, it is expected that domestic factors will shape the effects of global variables, but that - in spite of these effects - the impact of global interactions will persist. Finally, it is expected that poverty at the $\$ 1.25$ and $\$ 2.50$-a-day levels will be affected differently by these variables as these poverty levels may represent different types of poverty. By addressing these questions, this study fills gaps in the dependency/world-systems, world polity, and poverty literatures and provides insights for potential policy efforts toward poverty reduction at both the domestic and international levels.

\section{Methodology}

Data for the measures included in this study come from multiple sources that provide countrylevel data for international comparisons, including The United Nations, The World Bank, The Yearbook of International Organizations, and The Polity IV Project. While the data examined in this analysis are the best available for this type of research, limitations associated with crossnational research exist, particularly among poor populations. In spite of the challenges presented by the nature of these data, the efficacy of variables developed from these sources has been demonstrated in research in a number of areas including: world-systems (Clark and Beckfield 
2009), world polity (Meyer et al. 1997), human rights (Hafner-Burton and Tsutsui 2005), and refugee studies (Moore and Shellman 2007).

The World Bank Indicators (2010) database includes observations of poverty levels for 114 countries (see Appendix A for a list of included countries). These observations occur at regular intervals and these intervals are used as the center points of three-year waves. Using data from 1991 - 2005 allows for the creation of five waves of data, expanding the total possible observations to 570. However, due to differential availability of data for many of the included variables, some countries will not have observations for all of the waves of the study, resulting in pooled data that are unbalanced. Appropriate measures are therefore taken in handling these data as discussed in the Methods section of this paper.

Because the data for this project come from a variety of sources, variation exists in definitions, levels of measurement, and data manipulations. Whatever variation may exist, two commonalities are present across the dataset that allow for comparisons using these disparate data to be made. First, all of the data included are at the country or nation-state level. Whatever decisions were made in producing these data, they all share the same unit of analysis, which allows for comparability. Second, each measure uses a common data source for all observations. Whatever flaws may exist in the data, they will be consistent across all observations of a particular measure.

\section{Methods}

To examine the relationships between explanatory variables and poverty, the dataset was analyzed using random effects regression models (REMs). REMs are preferable for this analysis as they allow for comparisons of both between-country and within-country variations, making possible the observation of changes in the effects of independent variables in both cross-national and historical perspectives. This ability to make comparisons along these two vectors makes the use of random effects models preferable to fixed effects models (FEMs) that only capture variation within countries across time. Additionally, FEMs do not allow for the inclusion of time invariant variables, which would preclude the ability to control for regional variation. FEMs for all models in the analysis were conducted for robustness and these results are presented in Appendix B. These results demonstrate both similarities and differences to REMs findings. While many of the main REMs findings are confirmed, some relationships - particularly those identified in final models - fail to emerge in the FEMs results. This indicates that, to some extent, the effects identified in the REMs are the result of cross-sectional variation in experiences of the independent variables and poverty, and not the result of change in these variables across time in all countries. However, the primary relationships (i.e., FDI penetration, trade openness, and INGOs with poverty) are present in both REMs and FEMs, confirming that these effects occur both across countries and over time.

Pooled time series data, such as will be used here, have consistently demonstrated the tendency to violate the ordinary least squares (OLS) assumption of uncorrelated errors due to the likelihood of unmeasured heterogeneity in the panels (Lee, Nielsen, and Anderson 2007). The strong possibility exists that observations in the same country have correlated error. This correlation of error within panels due to time-invariant, unit-specific effects may bias the parameter estimates (Greene 2000). The use of random effects models is a common strategy for accounting for this error (Mahutga and Bandelj 2008), as these models adjust for error correlation through the inclusion of a panel-specific error term that is normally distributed. 
Because the analysis in this project evaluates relationships in waves, the variables used as predictors and controls are period averages for the years included in each period (1991-1993, 1994-1996, 1997-1999, 2000-2002, 2003-2005). The use of averages controls for variation resulting from changes that may have occurred in a particular country over the time being studied, allowing lag time for the effects of these variables on poverty to manifest. For some variables this information is not available and for others there is no need to calculate averages, given that scores do not change significantly over such a short span. Due to the highly skewed nature of many of these variables, a number of them are logged. Whether a variable is included as a period average, a simple score, or a logged transformation is noted in the descriptions of variables that follow. Pairwise correlations for all variables are presented in Appendix C. Additionally, collinearity checks were performed and all relationships were found to fall within accepted standards. Observations from all of the waves of the study will be included in this analysis. Descriptive statistics for all variables are presented in Appendix D.

\section{Dependent Variables - Poverty at the \$1.25- and \$2.50-a-day Levels}

Extreme and moderate poverty are the outcome variables for this analysis. The extreme poverty measure is presented as the percentage of a country's population living at or below $\$ 1.25$ a day. All dollar measures are in 2005 U.S. dollars adjusted for purchasing power parity (2005 PPP). In order to examine differences in the effects of variables in the analysis on poverty at different levels, a second set of analyses will be done with poverty percentages at the $\$ 2.50$ a day, or moderate poverty level. Data for these measures come from the World Bank (2010) and reflect estimates for countries based on a variety of sources collected from different years within the time period. Each country has a single score for each wave. The use of multiple sources for the poverty estimates creates some problems in terms of the reliability of the data (Chen and Ravallion 2007), and it is with full awareness of these potential flaws in the data that this analysis is conducted. These data are the standard measures of extreme poverty in spite of their flaws and provide a solid picture of trends in poverty at the national level.

\section{Globalization Variables}

The foreign direct investment (FDI) penetration (logged) variable measures the extent to which a country's economy is dependent on foreign investment. This measure is constructed by dividing FDI stock by total Gross Domestic Product (GDP). The data for FDI stock come from the United Nations Conference on Trade and Development (UNCTAD 2010) and the GDP numbers come from the World Bank's (2010) World Development Indicators Database (WDI). This measure is presented as a period average for each of the waves. For countries that do not have available data for all of the years of the period, available years will be averaged. A country must have data available for at least two years to be included in a given wave. The log of this variable is used in order to account for the skewed nature of the data.

Trade openness measures the level at which a particular nation participates in the world economy (Clark 2008). This variable includes all exports and imports and calculates the percentage of a country's total GDP accounted for by trade outside the country's borders. This measure is developed by summing total exports and imports as a share of total GDP and is presented as a period average for each wave. The data for this measure come from the World Bank. This variable is logged to account for the skewed nature of the data. 
The International Non-Governmental Organization (INGO) membership ties measure reflects the extent to which a country is connected to the world polity and examines the effects of that connection on poverty. Data for this measure come from the Yearbook of International Organizations (1996; 2002; 2005; 2008) and represent counts of organizational ties. As the distribution of these data demonstrates a degree of stability over time (Beckfield 2003), counts will be included for only one year in each of the waves.

\section{Domestic Variables}

GDP per capita, (logged) is a measure to account for economic growth. It is included as period averages for all of the years in each wave and is logged to account for skewness in the data. These data come from the WDI (World Bank 2010). While valid arguments can be made for the use of either purchansing power parity (Passe-Smith 2008) or fixed exchange (Korzeniewicz et al. 2004) data for this measure, we agree with Milanovic (2005: 13) that PPP provides "a much better handle on the real welfare of people," and use PPP for this analysis.

Domestic investment is a measure of the effects of resources spent within the country to encourage development. It is presented as domestic credit to the private sector as a percentage of GDP. Data for this measure come from the WDI (World Bank 2010).

Data for the democracy variable come from the Polity IV Index maintained by the University of Maryland's Center for International Development and Conflict Management (Marshall and Jaggers 2008). This index presents a country's level of democracy on a scale from -10 to 10 , with lower numbers representing lower scores on the component parts of the index. For this measure, scores are averaged across all of the years included in each wave. Adjustments have been made to the scores of several countries to account for transitional governments or foreign occupations. These adjustments were made according to the standards outlined by the developers of the index with careful attention to the way in which scores were imputed or translated. The inclusion of a measure of democracy that captures the level of democracy in a country (e.g., Bollen and Jackman 1985) - rather than one that captures the length of time a country has been democratic (e.g., Muller 1988) or simply measures democracy as a dichotomous variable (e.g., Lee 2005) - flows from the assertion by Kuznets (1955) and others that democracy creates greater equality through participation levels, and institutions that tend to exist in countries with higher levels of democracy.

The fertility rate is an indicator of the population pressures experienced by a country. It is the average number of births per female and expresses the expected number of children that a woman will bear if she survives to the end of her reproductive age span and experiences the given age-specific rate. Data for this measure come from the WDI (World Bank 2010).

Secondary school enrollment measures a country's level of formal education. Data are from the WDI (World Bank 2010) and capture the percentage of the secondary school-age population who are enrolled in school. While enrollment does not necessarily indicate attendance, higher enrollment levels generally indicate higher levels of participation.

\section{Control Variables}

Regional variation is captured in a series of dummy variables that control for the region in which a country is located. It is possible that a number of elements related to a country's regional location could affect the levels of extreme and/or moderate poverty in that country. Countries in 
the analysis are divided into six regions - Sub Saharan Africa, South Asia, Middle East/North Africa, Eastern Europe/Central Asia, Latin America/Caribbean, and East Asia and the Pacific. Location in a particular region is based on World Bank classifications (2010). These variables account for those elements that may not be captured in the domestic conditions variables. For each of the dummy variables, countries located within that region are coded "1," with all other countries coded " $0 . "$

Time period captures the waves represented in each observation and accounts for change over time.

\section{Analysis}

To address the questions in this analysis, a series of random effects regression models are examined with poverty measures at the $\$ 1.25$ and $\$ 2.50$ levels. The $\$ 1.25$ results are presented in Table 1, while the $\$ 2.50$ results are presented in Table 2. The first model in each table (Model 1) includes the global variables together with the appropriate poverty measure and controls. Model 2 includes all of the domestic variables with controls. In Model 3, the regional dummy variables are presented by themselves in order to examine these relationships unencumbered by additional variables. Finally, Model 4 includes all of the global, domestic, and control variables together.

\section{Results}

\section{What is related to \$1.25-a-day or extreme poverty?}

The effects of regional variables presented in Model 1 reflect the statistics reflected in Figure 1. Africa has a higher level of poverty relative to East Asia, while the Middle East, Latin America, and the former Soviet countries in Eastern Europe and Central Asia all demonstrate lower poverty levels. Of these variables, Eastern Europe/Central Asia has the strongest relationship, followed by Africa, Latin America, and the Middle East. Interestingly, South Asia does not demonstrate a significant relationship in this model. Time also reflects Figure 1, demonstrating a reduction in poverty over the course of years covered in this analysis. 
Table 1. Relationships with Extreme Poverty at the \$1.25-a-day Level

\begin{tabular}{|c|c|c|c|c|}
\hline & Model 1 & Model 2 & Model 3 & Model 4 \\
\hline \multicolumn{5}{|l|}{ Globalization variables } \\
\hline FDI penetration $(\log )$ & & $\begin{array}{l}.061 * \\
(.029)\end{array}$ & & $\begin{array}{l}.069 * \\
(.028)\end{array}$ \\
\hline Trade openness (log) & & $\begin{array}{l}-.118 * * * \\
(.031)\end{array}$ & & $\begin{array}{l}-.059 * \\
(.029)\end{array}$ \\
\hline INGO membership (log) & & $\begin{array}{l}-.099 * * \\
(.035)\end{array}$ & & $\begin{array}{l}.045 \\
(.034)\end{array}$ \\
\hline \multicolumn{5}{|l|}{ Domestic variables } \\
\hline GDP per capita (PPP) (log) & & & $\begin{array}{l}-.466 * * * \\
(.055)\end{array}$ & $\begin{array}{l}-.481 * * * \\
(.061)\end{array}$ \\
\hline Domestic investment & & & $\begin{array}{l}-.006 \\
(.030)\end{array}$ & $\begin{array}{l}-.002 \\
(.031)\end{array}$ \\
\hline Democracy & & & $\begin{array}{l}.002 \\
(.025)\end{array}$ & $\begin{array}{l}-.006 \\
(.027)\end{array}$ \\
\hline Fertility rate & & & $\begin{array}{l}.091 * \\
(.041)\end{array}$ & $\begin{array}{l}.098^{*} \\
(.041)\end{array}$ \\
\hline Secondary school & & & $\begin{array}{l}-.043 \\
(.053)\end{array}$ & $\begin{array}{l}-.052 \\
(.057)\end{array}$ \\
\hline \multicolumn{5}{|l|}{ Control Variables } \\
\hline Sub-Saharan Africa & $\begin{array}{l}.368 * * * \\
(.083)\end{array}$ & $\begin{array}{l}.388 * * * \\
(.073)\end{array}$ & $\begin{array}{l}.227 * * * \\
(.064)\end{array}$ & $\begin{array}{l}.244 * * * \\
(.064)\end{array}$ \\
\hline South Asia & $\begin{array}{l}.013 \\
(.016)\end{array}$ & $\begin{array}{l}.038^{*} \\
(.019)\end{array}$ & $\begin{array}{c}.045^{*} \\
(.018)\end{array}$ & $\begin{array}{l}.058 * * \\
(.019)\end{array}$ \\
\hline Middle East / North Africa & $\begin{array}{l}-.256 * * * \\
(.064)\end{array}$ & $\begin{array}{l}-.223 * * * \\
(.055)\end{array}$ & $\begin{array}{l}-.161 * * * \\
(.046)\end{array}$ & $\begin{array}{l}-.146^{* *} \\
(.045)\end{array}$ \\
\hline Eastern Europe / Central Asia & $\begin{array}{l}-.417 * * * \\
(.079)\end{array}$ & $\begin{array}{l}-.324 * * * \\
(.069)\end{array}$ & $\begin{array}{l}-.187 * * \\
(.067)\end{array}$ & $\begin{array}{l}-.125 \dagger \\
(.068)\end{array}$ \\
\hline Latin America / Caribbean & $\begin{array}{l}-.316 * * * \\
(.078)\end{array}$ & $\begin{array}{l}-.266 * * * \\
(.068)\end{array}$ & $\begin{array}{l}-.111 \dagger \\
(.060)\end{array}$ & $\begin{array}{l}-.084 \\
(.060)\end{array}$ \\
\hline Time period & $\begin{array}{l}-.091 * * * \\
(.012)\end{array}$ & $\begin{array}{l}-.072 * * * \\
(.018)\end{array}$ & $\begin{array}{l}-.042 * * \\
(.016)\end{array}$ & $\begin{array}{l}-.049 * \\
(.020)\end{array}$ \\
\hline Observations & 570 & 471 & 467 & 408 \\
\hline Countries & 114 & 112 & 108 & 106 \\
\hline $\mathrm{R}^{2}$ Within & .15 & .16 & .23 & .26 \\
\hline $\mathrm{R}^{2}$ Between & .63 & .69 & .82 & .82 \\
\hline $\mathrm{R}^{2}$ Overall & .60 & .64 & .80 & .79 \\
\hline
\end{tabular}

Notes: Six random effects regression models (REMs) examine what globalization and domestic variables are significantly related to poverty at the $\$ 1.25$-a-day level. All models include a first-order autocorrelation correction. Each cell reports the standardized coefficient with the standard error in parentheses. In bivariate regressions, the global variables each demonstrated the similar relationships and levels of significance. Additionally, the full model was run without GDP per capita to check for the possible influence of collinearity. Relationships and significance remained robust in this model (FDI penetration, $\mathrm{p}=.037$; Trade openness, $\mathrm{p}=.005$; INGO membership, $\mathrm{p}=.139$ ). 
Model 2 of Table 1 demonstrates that significant relationships exist between each of the global variables and poverty at the \$1.25-a-day level. Higher levels of FDI lead to increased levels of poverty while trade openness and INGO participation both reduce poverty levels. Of these global variables, trade openness demonstrates the strongest effect on poverty. In this model the effects of most of the regional variables decrease, however, the positive relationship demonstrated by Africa becomes stronger and the positive relationship between South Asia and poverty becomes significant. This indicates that the influence of these global interactions increases poverty levels across regions, relative to East Asia. Time continues to demonstrate a negative relationship with poverty in this model.

In the domestic model presented in Model 3, GDP per capita and fertility demonstrate significant relationships, with increases in GDP per capita leading to decreased poverty while increases in fertility lead to increases in poverty. Domestic investment, democracy, and secondary school enrollment do not demonstrate significant relationships in this model. The effects of regional variation are reduced for most regions, with South Asia as the exception. These changes indicate that some of the effect of regional status is explained by the domestic conditions included in the analysis.

The full model, Model 4, demonstrates few changes from the previous three models, the most important of which is the failure of INGO membership to reach significance net of the domestic conditions included in this model. FDI maintains significance, as does the negative effect of trade openness. Interestingly, the effect of FDI becomes slightly stronger in this model (.061 versus .069). GDP per capita and fertility remain significant among the domestic variables, while the regional variables exhibit movement toward greater levels of poverty (i.e., positive relationships becomes stronger and negative relationships become weaker). The persistent significant effect of trade openness in this model is an unexpected finding and demonstrates that countries experience benefits from greater trade, net of internal conditions. Equally surprising is the lack of effect demonstrated by the INGO measure. All other significant variables show effects in expected directions (i.e., positive for FDI, and the fertility rate, while negative for GDP per capita). It is worth noting that, while significant, the effects of the FDI and trade openness are weaker than those of the significant domestic conditions; however, the persistence of these global variables net of domestic conditions is an important discovery and agrees with our expectations. 
What is related to $\$ 2.50$-a-day or moderate poverty?

Table 2. Relationships with Moderate Poverty at the \$2.50-a-day Level

\begin{tabular}{|c|c|c|c|c|}
\hline & Model 1 & Model 2 & Model 3 & Model 4 \\
\hline \multicolumn{5}{|l|}{ Globalization variables } \\
\hline FDI penetration $(\log )$ & & $\begin{array}{l}.064 * \\
(.027)\end{array}$ & & $\begin{array}{l}.060 * * \\
(.024)\end{array}$ \\
\hline Trade openness (log) & & $\begin{array}{l}-.124 * * * \\
(.029)\end{array}$ & & $\begin{array}{l}-.049 * \\
(.025)\end{array}$ \\
\hline INGO membership (log) & & $\begin{array}{l}-.156^{* * * *} \\
(.032)\end{array}$ & & $\begin{array}{l}-.004 \\
(.029)\end{array}$ \\
\hline \multicolumn{5}{|l|}{ Domestic variables } \\
\hline GDP per capita (PPP) (log) & & & $\begin{array}{l}-.552 * * * \\
(.044)\end{array}$ & $\begin{array}{l}-.561 * * * \\
(.050)\end{array}$ \\
\hline Domestic investment & & & $\begin{array}{l}-.055^{*} \\
(.026)\end{array}$ & $\begin{array}{l}-.045 \dagger \\
(.027)\end{array}$ \\
\hline Democracy & & & $\begin{array}{l}.009 \\
(.022)\end{array}$ & $\begin{array}{l}-.001 \\
(.023)\end{array}$ \\
\hline Fertility rate & & & $\begin{array}{l}.017 \\
(.032)\end{array}$ & $\begin{array}{l}.016 \\
(.033)\end{array}$ \\
\hline Secondary school & & & $\begin{array}{l}-.232 \\
(.602)\end{array}$ & $\begin{array}{l}-.039 \\
(.048)\end{array}$ \\
\hline \multicolumn{5}{|l|}{ Control Variables } \\
\hline Sub-Saharan Africa & $\begin{array}{l}.143 \dagger \\
(.082)\end{array}$ & $\begin{array}{l}.130 \dagger \\
(.068)\end{array}$ & $\begin{array}{l}-.009 \\
(.050)\end{array}$ & $\begin{array}{l}-.002 \\
(.051)\end{array}$ \\
\hline South Asia & $\begin{array}{l}-.003 \\
(.015)\end{array}$ & $\begin{array}{l}.020 \\
(.018)\end{array}$ & $\begin{array}{l}.029 \dagger \\
(.016)\end{array}$ & $\begin{array}{l}.033^{*} \\
(.017)\end{array}$ \\
\hline Middle East / North Africa & $\begin{array}{l}-.293 * * * \\
(.063)\end{array}$ & $\begin{array}{l}-.262 * * * \\
(.051)\end{array}$ & $\begin{array}{l}-.185 * * * \\
(.036)\end{array}$ & $\begin{array}{l}-.176^{* * * *} \\
(.036)\end{array}$ \\
\hline Eastern Europe / Central Asia & $\begin{array}{l}-.630 * * * \\
(.078)\end{array}$ & $\begin{array}{l}-.546 * * * \\
(.064)\end{array}$ & $\begin{array}{l}-.398 * * * \\
(.053)\end{array}$ & $\begin{array}{l}-.354 * * * \\
(.055)\end{array}$ \\
\hline Latin America / Caribbean & $\begin{array}{l}-.500 * * * \\
(.076)\end{array}$ & $\begin{array}{l}-.453 * * * \\
(.064)\end{array}$ & $\begin{array}{l}-.286^{* * * *} \\
(.047)\end{array}$ & $\begin{array}{l}-.263^{* * * *} \\
(.049)\end{array}$ \\
\hline Time period & $\begin{array}{l}-.061 * * * \\
(.054)\end{array}$ & $\begin{array}{l}-.036^{*} \\
(.017)\end{array}$ & $\begin{array}{l}-.023 \dagger \\
(.013)\end{array}$ & $\begin{array}{l}-.022 \\
(.017)\end{array}$ \\
\hline Observations & 570 & 471 & 467 & 408 \\
\hline Countries & 114 & 112 & 108 & 106 \\
\hline $\mathrm{R}^{2}$ Within & .08 & .11 & .22 & .26 \\
\hline $\mathrm{R}^{2}$ Between & .64 & .72 & .89 & .89 \\
\hline $\mathrm{R}^{2}$ Overall & .62 & .69 & .87 & .87 \\
\hline
\end{tabular}

Notes: Six random effects regression models (REMs) examine what globalization and domestic variables are significantly related to poverty at the $\$ 1.25$-a-day level. All models include a first-order autocorrelation correction. Each cell reports the standardized coefficient with the standard error in parentheses. In bivariate regressions, the global variables each demonstrated the similar relationships and levels of significance. Additionally, the full model was run without GDP per capita to check for the possible influence of collinearity. Relationships and levels of significance remained robust in this model (FDI penetration, $\mathrm{p}=.043$; Trade openness, $\mathrm{p}=.003$; INGO membership, $\mathrm{p}=.538$ ). 
As in the $\$ 1.25$ analysis, the regional variables in Model 1 generally reflect the conditions presented in Figure 2. The Middle East, Eastern Europe, and Latin America all demonstrate lower levels of poverty relative to East Asia. South Asia again fails to reach significance in this model, while the positive relationship of Africa is only marginally significant $(p=.079)$. In Model 2, each global variable demonstrates significance in the expected direction. Higher levels of FDI penetration are related to greater poverty, while greater trade openness and INGO participation are related to lower levels of poverty at the $\$ 2.50$ threshold. In the domestic model presented in Model 3, secondary school enrollment and democracy fail to achieve significance while GDP per capita persists in its significant negative relationship with poverty. Unlike the $\$ 1.25$ analysis, however, fertility fails to reach significance with poverty at the $\$ 2.50$ level, while domestic investment demonstrates a significant negative relationship. As in the $\$ 1.25$ analysis, the inclusion of domestic conditions in Model 3 greatly reduces the strength of the impact of the regional variables and causes time to become only marginally significant.

In Model 4, the full model, INGO participation is no longer significant but FDI maintains a positive, significant relationship, and trade openness maintains a significant - though greatly weakened - negative relationship. Among the domestic conditions, GDP per capita maintains significance, while domestic investment falls to only marginal significance. As in the extreme poverty analysis, each of the significant regional variables shares a negative relationship with poverty in this full model. Of the significant variables, GDP per capita again exhibits the strongest effect, demonstrating the importance of growth as a strategy for poverty reduction at this level as well.

\section{Discussion}

\section{The Effects of Global Interactions and Domestic Conditions on Poverty}

A chief contribution of this research is the demonstration of the consistent, harmful effects of foreign direct investment (FDI) on poverty in the developing world. Similar to the negative impact of FDI found on manufacturing wages in Vijays and Kaltani's (2007) cross-country investigation, greater levels of FDI penetration yield higher levels of poverty at both the $\$ 1.25$ and $\$ 2.50$ poverty levels. The persistence of this effect net of other significant domestic variables demonstrates that gains in poverty reduction that can occur as a product of economic growth or educational development may be hampered by the presence of high levels of FDI. While this study is unable to investigate the ways in which FDI influences poverty, this finding is an important addition to the ongoing conversation about the role of FDI in development. Our finding that FDI has a negative impact on welfare outcomes in poor countries aligns with other world-systems scholars (Dixon and Boswell 1996; Kentor 1998).

The unexpected persistence of the beneficial effects of trade openness net of domestic conditions is an interesting finding that demonstrates a clear distinction between different types of global economic interaction. While foreign investment is related to increased poverty, participation in foreign trade leads to lower poverty at both the $\$ 1.25$ and $\$ 2.50$ levels. The trade finding supports the neoclassical perspective (Wacziarg and Welch 2008) and demonstrates that the pursuit of greater levels of international trade is a viable strategy for the reduction of both extreme and moderate poverty in developing countries. 
The failure of the predicted negative effect of globalization in the form of international non-governmental organization (INGO) participation on poverty to emerge net of domestic factors is another interesting and important finding of this analysis. While the presence of INGOs in the developing world has clearly demonstrated positive outcomes in a number of areas related to human welfare, poverty reduction is not among these outcomes when domestic conditions are considered. This finding provides mixed support for world polity theory as INGOs do perform as expected in a global context, but fail to maintain their effect in a more integrated model. As there is a significant negative effect in the global model, it may be that the poverty-reducing benefits of the presence of INGOs present themselves in areas like secondary school education and fertility reduction, causing the presence of these variables to negate the significance of INGOs in the models in which they appear.

In addition to the effects of the global variables, the identification of significant relationships between poverty and the domestic variables represents another substantial contribution of this study. Among these variables, a key finding is the consistent role of economic growth in poverty reduction at both the $\$ 1.25$ and $\$ 2.50$ levels. Gross domestic product per capita growth demonstrates the strongest negative effect on poverty in every model in which it appears, supporting the findings of Framingham (2005) and providing support for the position that economic growth is an important factor in determining welfare outcomes (Firebaugh and Beck 1994). However, while this study finds that economic growth clearly has an important effect on poverty in the developing world, this effect does not completely overwhelm other elements from having positive and negative independent effects on poverty, demonstrating that economic growth is not the only factor at play in efforts to address poverty. While issues like fertility and domestic investment are certainly affected by economic conditions within a country, this study demonstrates that these factors affect poverty above and beyond their connection to the economy.

The differences demonstrated between random effects and fixed effects models for the relationships in this study are noteworthy. FEMs results (presented in Appendix B) show fewer significant effects than those present in the REMs results, particularly in the final models (Model 4 ). This indicates that the effects noted for the global variables are largely a function of crosssectional differences between countries in their experiences of these conditions and that longitudinal change within countries is less important. However, it is important to note that many of the relationships identified in the REMs are also present in the FEMs, indicating that both cross-sectional and longitudinal variation impact the experience of poverty at both levels.

Finally, this study demonstrates clear regional trends in both extreme and moderate poverty. While elements like the domestic conditions included in this study explain some of the differential experience of poverty present in these regions, the persistence of the impact of these variables indicate that other factors are at play as well. Colonial history, ethnic and political conflict, slavery, geography, natural resources, and health also differentially shape the presence of poverty across these regions. As many of these influences are key components of the worldsystems paradigm, examining their effects on regional variation in poverty reduction is an important area for further study. 


\section{Evaluation of Research Questions}

The first question of this study involves an examination of the effects of global interaction variables on poverty in countries with a population living at either the $\$ 1.25$ - or $\$ 2.50$-a-day level. When the globalization variables are taken together, FDI penetration, trade openness, and INGO participation each has a significant effect on poverty at both levels. The presence of FDI increases poverty levels while greater trade openness and INGO participation reduce those levels. The fact that each of these effects persists, net of each other, in the global models (i.e., Model 2 of Table 1 and Table 2, respectively) highlights the key role that each can play in poverty reduction strategies for developing countries.

In evaluating the persistence of the effects of these global variables net of domestic influences, a varied picture emerges. All of the effect of INGO participation at either level of poverty is absorbed by the presence of domestic conditions. This indicates that benefits experienced by poor countries through their level of INGO participation on poverty come through the domestic conditions that these organizations foster. In contrast, FDI maintains a significant positive relationship with poverty and trade openness a significant negative effect at both levels in spite of the inclusion of domestic conditions (e.g., GDP per capita and the fertility rate at the $\$ 1.25$ poverty level, and GDP per capita and domestic investment at the $\$ 2.50$ poverty level).

Few clear differences emerge in the effects of the global variables at the $\$ 1.25$ and $\$ 2.50$ levels. In fact, the only real difference is an increase in the effects of these variables in the global model of the $\$ 2.50$ analysis, followed by smaller coefficients in the full model of this analysis. Other differences identified between these levels of poverty are the significance of fertility and domestic investment at different levels. Higher fertility leads to greater levels of poverty at the $\$ 1.25$ level, but is not significant at the $\$ 2.50$ level while domestic investment exhibits the opposite effect. Domestic investment levels are not significant at the $\$ 1.25$ level, but lead to lower poverty at the $\$ 2.50$ level. Understanding the effects of these variables and their persistence in light of both global factors and the strong effect of GDP per capita is an important area of further analysis with implications for poverty reduction.

Another difference in the $\$ 1.25$ and $\$ 2.50$ analyses is the increased strength of the effect of economic growth (measured as GDP per capita) at the $\$ 2.50$ level (i.e., -.481 compared to .561 respectively in the full models). This difference may reflect differences that exist in the types of people who experience poverty at these different levels. While economic growth clearly benefits both groups, those at the $\$ 2.50$ level may be in a better position to take advantage of benefits accrued due to economic growth. This may be a difference in urban versus rural poverty, level of education, or a product of differences in family structure or racial/ethnic position. Whatever the reason, it is clear that those at a slightly higher income level are better able to accrue benefits from growth. Additional research on the differences in these types of poverty and the effects of different factors on them may produce ideas about what interventions and policy decisions will have the most beneficial impact on the poorest members of a society.

While this study provides important insight into factors that affect extreme poverty in the developing world, the limited sample of countries available for this study must be acknowledged. The sample is limited to those countries that 1 ) have a large enough population living in extreme poverty to be counted and 2) have adequate data on that population to be included in the World Bank data. This means that a number of wealthier, developed countries were not eligible for the study due to their lack of population in extreme poverty. Also, many of the poorest countries in 
the world were excluded due to a lack of data, a problem often produced by the absence of resources necessary to estimate the level of poverty present within their borders. Additionally, nations with large percentages of their population displaced by famine, conflict, or drought cannot adequately survey these populations to develop usable numbers for studying poverty. Finally, some countries were excluded that had poverty data but lacked data on the explanatory variables. While the sample is limited, examining relationships over a number of waves allows for a larger sample size and commensurate number of comparisons. This constraint highlights the ongoing need for better data collection methods and efforts geared at developing information about some of the poorest populations.

Limitations related to the data available for independent variables should be acknowledged. Measures of government spending and trade structure were excluded due to the loss of cases brought about when these measures were included in the models. In addition to the high level of missing data across countries of interest, the government spending measure was found to be highly collinear with GDP per capita, so we excluded government spending from the final analysis in order to preserve sample size while safeguarding the reliability of the estimates being modeled. Excluding trade structure limits our ability to test completely the efficacy of the world-systems perspective in this analysis, as some of this argument is predicated on the different type of trade experienced by poor countries, not just participation in trade relationships. When trade structure was included in the analysis for countries with available data (results not presented), it was not found to be significant across all models, and when it was excluded, the overall findings did not change substantively. The lack of significant findings for this measure indicates that, in this instance, the presence of trade may be more important with respect to poverty reduction than the nature of that trade. Moreover, these acknowledged data limitations and additional findings underscore the balancing act often inherent in the analytic process when using these types of data.

\section{Conclusion}

The findings on the effect of foreign direct investment on poverty in the developing world represent a key contribution of this study and provide support for the world-systems argument. The consistency of this effect in the face of other global and domestic variables clearly demonstrates the potentially problematic nature of developing economies relying on foreign investment to reduce poverty. Alternatively, trade openness presents a stronger than anticipated effect on poverty, providing support for the neoclassical argument. Finally, the lack of a persistent effect of INGO membership ties on poverty at either level net of domestic conditions is an unexpected outcome. World polity theory and previous research would hold that INGO ties should have a strong influence on poverty, and the lack of impact when domestic variables are considered indicates that conditions "on the ground" hold greater sway than globalization interactions or that the benefits of INGOs take place through their effect on domestic conditions.

Despite some data limitations and corresponding implications for the findings reported, this study reveals a number of relationships and introduces new questions that should be examined in future analyses. Further research is necessary to disaggregate the nature of the relationship between poverty and FDI penetration or trade openness, as well as GDP per capita, fertility, and domestic investment. As income inequality is associated with many of the welfare outcomes examined in this study, future research should examine the relationship between 
inequality and poverty in light of global interactions. Additionally, demonstrated differences in the strength of the effects of global variables between poverty at the $\$ 1.25$-a-day and $\$ 2.50$-a-day levels should be examined to understand how these levels of poverty are different at the macro level and how intervention strategies might be tailored to address these differences. The differential effect of the domestic variables on these levels is another intriguing area for exploration. Finally, examining the persistent impact of regional variation on poverty at both levels, net of domestic conditions and globalization interactions, is vital to ongoing efforts to reduce poverty levels in the poorest regions. Future studies should consider historical, geographic, political, and health factors.

This study speaks to public policy and the first United Nations Millennium Development Goal as it examines global and domestic variables to discern their effects on the percentage of a country's population living in extreme poverty. Additionally, this study examines both extreme and moderate poverty, finding differences in what shapes poverty at these different levels. Policy and development experts should note that what is relevant at the extreme poverty level is not always relevant at the moderate poverty level (e.g., fertility rate). The application of panel data over a number of waves and countries provides a broader picture of how these variables operate across time and geographic space. By finding a number of variables that impact poverty in both positive and negative directions, this study expands conversations in the neoclassical, world-systems, world polity and development literatures and provides a number of avenues for future study.

\section{References}

Abernethy, Virginia D. 2002. "Population Dynamics: Poverty, Inequality, and Self-regulating Fertility Rates." Population and Environment 24(1): 69-96.

Agenor, Richard Pierre. 2002. Does Globalization Hurt the Poor? Mimeograph, Washington, DC: World Bank.

Anyanwu, John C. 2006. "Promoting Investment in Africa." African Development Review 18(1): 42-71.

Barro, Robert J. 2001. "Human Capital and Growth.” The American Economic Review 91(2): 1227.

Beckfield, Jason. 2003. "Inequality in the World Polity: The Structure of International Organization." American Sociological Review 68: 401-424.

Bello, Walden. 2001. "Global Civil Society: Promise and Pitfalls." Pp. 227-230 in The Future in the Balance, edited by A. Mittal. Oakland, CA: Food First Books.

Bloom, David E. and Jeffrey D. Sachs. 1998. "Geography, Demography, and Economic Growth in Africa." Brookings Papers on Economic Activity 2: 207-273.

Boli, John and George M. Thomas. 1997. "World Culture in the World Polity: A Century of International Non-governmental Organizations." American Sociological Review 62(2): 171-190.

-----. 1999. "INGOs and the Organization of World Culture." Pp. 13-49 in Constructing World Culture: International Nongovernmental Organizations Since 1875, edited by J. Boli and G. M. Thomas. Stanford: Stanford University Press. 
Bollen, Kenneth 1980. "Issues in the Comparative Measurement of Political Democracy." American Sociological Review 45: 370-390.

Bollen, Kenneth and Robert W. Jackman. 1989. "Democracy, Stability, and Dichotomies." American Sociological Review 54: 612-621.

Bradshaw, York W. and Jie Huang. 1991. "Intensifying Global Dependency: Foreign Debt, Structural Adjustment, and Third World Underdevelopment." The Sociological Quarterly 32(3): 321-342.

Bradshaw, York W., Rita Noonan, Laura Gash, and Claudia Buchmann Sershen. 1993. "Borrowing against the Future: Children and Third World Indebtedness." Social Forces 71(3): 629-656.

Bradshaw, York W. and Mark J. Schafer. 2000. "Urbanization and Development: The Emergence of International Nongovernmental Organizations amid Declining States." Sociological Perspectives 43(1): 97-116.

Brady, David, Yunus Kaya, and Jason Beckfield. 2007. "Reassessing the Effect of Economic Growth on Well-Being in Less-Developed Countries, 1980 - 2003.” Studies in Comparative International Development 42: 1-35.

Carkovic, Maria and Ross Levine. 2002. Does Foreign Direct Investment Accelerate Growth? Mimeograph, Minneapolis: University of Minnesota.

Carneiro, Francisco G. and Jorge S. Arbache. 2003. "Assessing the impact of trade on poverty and inequality." Applied Economics Letters 10(15): 989-994.

Chabbott, Colette. 1999. "Development INGOs." Pp. 222-248 in Constructing World Culture: International Nongovernmental Organizations Since 1875, edited by J. Boli and G. M. Thomas. Stanford: Stanford University Press.

Chen, Shaohua and Martin Ravallion. 2007. "Absolute Poverty Measures for the Developing World, 1981-2004." Washington, DC: Development Research Group, World Bank.

------. 2008. The Developing World is Poorer than We Thought, but No Less Successful in the Fight against Poverty. Policy Research Working Paper 4703. Washington, DC: The World Bank Development Research Group. Accessed December 29, 2010 (http://econ.worldbank.org).

Clark, Rob. 2008. "Dependency, Network Integration, and Development." Sociological Perspectives 51: 629-648.

Clark, Rob and Jason Beckfield. 2009. "A New Trichotomous Measure of World-System Position Using the International Trade Network." International Journal of Comparative Sociology 50(5): 5-38.

Collier, Paul. 2007. The Bottom Billion: Why the Poorest Countries in the World are Failing and What Can Be Done About It. Oxford: Oxford University Press.

Crenshaw, Edward. 1992. "Cross-national Determinants of Income Inequality: A Replication and Extension Using Ecological-evolutionary Theory.” Social Forces 71(2): 339-363.

De Soysa, Indra and John R. Oneal. 1999. "Boon or Bane? Reassessing the Productivity of Foreign Direct Investment.” American Sociological Review 64(5): 766-782.

Dixon, Wilfrid J. and Terry Boswell. 1996. "Dependency, Disarticulation, and Denominator Effects: Another Look at Foreign Capital Penetration.” American Journal of Sociology 102(2): 543-562.

Dollar, David and Aart Kraay.2001. Trade, Growth and Poverty. Mimeograph, Washington, DC: World Bank. 
Eastwood, Robert and Michael Lipton. 1999. "The Impact of Changes in Human Fertility on Poverty." Journal of Development Studies 36(1): 1-30.

Edwards, Sebastian, Jeffrey Sachs, Andrew W. For, Francisco Rodriguez, and Dani Rodrik. 2007. "Trade Policy and Economic Growth." Scientific Commons. Accessed January 7, 2011. (http://en.scientificcommons.org/42869443).

Falkingham, Jane. 2005. "The End of the Rollercoaster? Growth, Inequality, and Poverty in Central Asia and the Caucasus." Social Policy and Administration 39(4): 340-360.

Firebaugh, Glenn. 1992. "Growth Effects of Foreign and Domestic Investment." American Journal of Sociology 98: 105-130.

------. 2003. The New Geography of Global Income Inequality. Cambridge, MA: Harvard University Press.

Firebaugh, Glenn and Frank D. Beck. 1994. "Does Economic Growth Benefit the Masses? Growth, Dependence, and Welfare in the Third World." American Sociological Review 59(5): 631-653.

Goesling, Brian and Glenn Firebaugh. 2004. "The Trend in International Health Inequality." Population and Development Review 30(1): 131-146.

Greene, William H. 2000. Econometric Analysis. $4^{\text {th }}$ edition. Upper Saddle River, NJ: Prentice Hall.

Hafner-Burton, Emilie M. and KiyoteruTsutsui. 2005. "Human Rights in a Globalizing World: The Paradox of Empty Promises." The American Journal of Sociology 110(5): 13731411.

Jalilian, Hossein and Colin Kirkpatrick. 2005. "Does Financial Development Contribute to Poverty Reduction?” Journal of Development Studies 41(4): 636-656.

Jalles, Joao Tovar. 2011. "Growth, Poverty, and Inequality: Evidence from Post-Communist Economies." Journal of Poverty 15(3): 277-308.

Jenkins, J. Craig and Stephen Scanlan. 2001. "Food Security in Less Developed Countries, 1970 to 1990." American Sociological Review 66: 718-744.

Jorgenson, Andrew K. 2009. "The Sociology of Unequal Exchange in Ecological Context: A Panel Study of Lower-income Countries, 1975-2000.” Sociological Forum 24(1): 22-46.

Kentor, Jeffrey. 1998. "The Long-term Effects of Foreign Investment Dependence on Economic Growth, 1940-1990.” The American Journal of Sociology 103(4): 1024-1046.

-----. 2001. "The Long Term Effects of Globalization on Income Inequality, Population Growth, and Economic Development." Social Problems 48(4): 435-455.

Kentor, Jeffrey and Terry Boswell. 2003. "Foreign Capital Dependence and Development: A New Direction.” American Sociological Review 68(2): 301-313.

Kerbo, Harold. 2006. World poverty: Global Inequality and the Modern World System. Boston: McGraw-Hill.

Kim, Sangmoon and Eui-Hang Shin. 2002. "A Longitudinal Analysis of Globalization and Regionalization in International Trade: A Social Network Approach." Social Forces 81(2): 445-471.

Korzeniewicz, Roberto Patricio, Angela Stach, Vrushali Patil, and Timothy Patrick Moran. 2004. "Measuring National Income: A Critical Assessment." Comparative Studies in Society and History 46(3): 535-586.

Kuznets, Simon. 1955. "Economic Growth and Income Inequality." American Economic Review 45: $1-28$. 
Lee, Cheol-Sung. 2005. "Income Inequality, Democracy, and Public Sector Size." American Sociological Review 70: 158-181.

Lee, Cheol-Sung, Francois Nielsen, and Arthur Alderson. 2007. "Income Inequality, Global Economy, and the State." Social Forces 86: 77-111.

Mahutga, Matthew and Nina Bandelj. 2008. "Foreign Investment and Income Inequality: The Natural Experiment of Central and Eastern Europe." International Journal of Comparative Sociology 49: 429-454.

Marshall, Monty G. and Keith Jaggers. 2008. "Political Regime Characteristics and Transitions, 1800-2004 (Polity IV).” Center for International Development and Conflict

Management, University of Maryland, College Park. Retrieved December 26, 2010 (http://www.cidem.umd.edu/polity/).

Meyer, John, John Boli, George Thomas, and Francisco Ramirez. 1997. "World Society and the Nation-State." American Journal of Sociology 103: 144-181.

Milanovic, Branko. 2002. Can We Discern the Effect of Globalization on Income Distribution? Mimeograph, Washington, DC: World Bank.

-----. 2005. Worlds Apart: Measuring International and Global Inequality. Princeton: Princeton University Press.

Moore, William H. and Stephen M. Shellman. 2007. "Whither Will They Go? A Global Study of Refugees' Destinations, 1965-1995.” International Studies Quarterly 51: 811-834.

Muller, Edward. N. 1988. "Democracy, Economic Development, and Income Inequality." American Sociological Review 53: 50-68.

Ndegwa, Stephen. 1996. The Two Faces of Civil Society: NGOs and Politics in Africa. New York: Kumarian Press.

Oneal, John R. and Bruce Russett. 2003. "Causes of Peace: Democracy, Interdependence, and International Organizations." International Studies Quarterly 47(3): 371-393.

Passe-Smith, John T. 2008. "Assessing Contending Measures of the Income Gap." Pp. 53-72 in Development and Underdevelopment: The Political Economy of Global Inequality, edited by M.A. Seligson and J.T. Passe-Smith. Boulder, CO: Lynne Rienner.

Pernia, Ernesto M. and Pilipinas F. Quising. 2003. "Trade Openness and Regional Development in a Developing Country." Annals of Regional Science 37(3): 391-406.

Ravallion, Martin. 2006. "Looking beyond Averages in the Trade and Poverty Debate." World Development 34(8): 1374-1392.

Ravallion, Martin, Shaohua Chen, Prem Sangruala. 2008. Dollar a Day Revisited. Policy Research Working Paper 4620. Washington, DC: The World Bank Development Research Group. Accessed January 6, 2011 (http://econ.worldbank.org).

Sachs, Jeffrey D. 2005. The End of Poverty: Economic Possibilities for Our Time. New York: Penguin Press.

Sachs, Jeffrey and Andrew Warner. 1995. "Economic Reform and the Process of GlobalIntegration." Brookings Papers on Economic Activity 1995: 1-95.

Sala-I-Martin, Xavier. 2006. "The World Distribution of Income: Falling Poverty and Convergence, Period." The Quarterly Journal of Economics 71(2): 351-397.

Salamon, Lester M. 1994. "The Rise of the Nonprofit Sector." Foreign Affairs 73(4): 109-122.

Schofer, Evan and John Meyer. 2005. "The Worldwide Expansion of Higher Education in the Twentieth Century." American Sociological Review 70: 898-920.

Shirin, Madon. 2000. "The Internet and Socio-Economic Development: Exploring the Interaction." Information Technology \& People 13(2): 85-101. 
Simpson, Miles. 1990. "Political Rights and Income Inequality: A Cross-national Test." American Sociological Review 55(5): 682-693.

Soros, George. 2004. The Bubble of American Supremacy: Correcting the Misuse of American Power. New York: Public Affairs.

Sumner, Andrew. 2005. "Is Foreign Direct Investment Good for the Poor? A Review and Stocktake." Development in Practice 15(3-4): 269-285.

Union of International Associations. 1996. Yearbook of International Organizations. Munich: K.G. Saur.

-----. 2002. Yearbook of International Organizations. Munich: K.G. Saur.

-----. 2005. Yearbook of International Organizations. Munich: K.G. Saur.

-----. 2008. Yearbook of International Organizations. Munich: K.G. Saur.

United Nations. 2007. The Millennium Development Goals Report 2007. New York.

-----. 2009. The Millennium Development Goals Report 2009. New York.

-----. 2010. The Millennium Development Goals Report 2010. New York.

Vijaya, Ramya M. and Linda Kaltani. 2007. "Foreign Direct Investment and Wages: A Bargaining Power Approach." Journal of World-Systems Research 13(1): 83-95.

Wallerstein, Immanuel. 1974. The Modern World-System. New York: Academic Press.

Wacziarg, Romain and Karen Horn Welch. 2008. "Trade Liberalization and Growth: New Evidence." World Bank Economic Review 22(2): 187-231.

Weede, Erich. 2008. "Globalization and Inequality." Comparative Sociology 7(4): 415-433.

Wimberley, Dale and Rosario Bello. 1992. "Effects of Foreign Investment, Exports, and Economic Growth on Third World Food Consumption." Social Forces 70: 895-921.

World Bank. 2010. World Development Indicators Database. Accessed June 6, 2010 (http://data.worldbank.org).

Yannikkaya, Halit. 2003. "Trade Openness and Economic Growth: A Cross-country Empirical Investigation." Journal of Development Economics 72: 57-89. 


\section{Appendix A. Countries Included in the Analysis}

\begin{tabular}{|llll|}
\hline Albania & Cote d'Ivoire & Lao PDR & Rwanda \\
Algeria & Croatia & Latvia & Senegal \\
Angola & Czech Republic & Lesotho & Sierra Leone \\
Argentina & Djibouti & Liberia & Slovak Republic \\
Armenia & Dominican Rep. & Lithuania & Slovenia \\
Azerbaijan & Ecuador & Macedonia & South Africa \\
Bangladesh & Egypt & Malawi & Sri Lanka \\
Belarus & El Salvador & Malaysia & St. Lucia \\
Benin & Estonia & Mali & Suriname \\
Bhutan & Ethiopia & Mauritania & Swaziland \\
Bolivia & Gabon & Mexico & Tajikistan \\
Bosnia and Herzegovina & The Gambia & Republic of Moldova & Tanzania \\
Botswana & Georgia & Mongolia & Thailand \\
Brazil & Ghana & Morocco & Togo \\
Bulgaria & Guatemala & Mozambique & Trinidad and Tobago \\
Burkina Faso & Guinea & Namibia & Tunisia \\
Burundi & Guinea-Bissau & Nepal & Turkey \\
Cambodia & Guyana & Nicaragua & Turkmenistan \\
Cameroon & Haiti & Niger & Uganda \\
Cape Verde & Honduras & Nigeria & Ukraine \\
Central African Rep. & Hungary & Pakistan & Uruguay \\
Chad & India & Panama & Uzbekistan \\
Chile & Indonesia & Papua New Guinea & Venezuela \\
China & Iran & Paraguay & Vietnam \\
Colombia & Jamaica & Peru & Yemen \\
Comoros & Jordan & Philippines & Zambia \\
DR Congo & Kazakhstan & Poland & \\
Congo & Kenya & Romania & \\
Costa Rica & Kyrgyz Rep. & Russian Federation & \\
& & & \\
\hline
\end{tabular}




\section{Appendix B. Results from Fixed Effects Models}

Table B1. Relationships with Extreme Poverty at the \$1.25-a-day Level

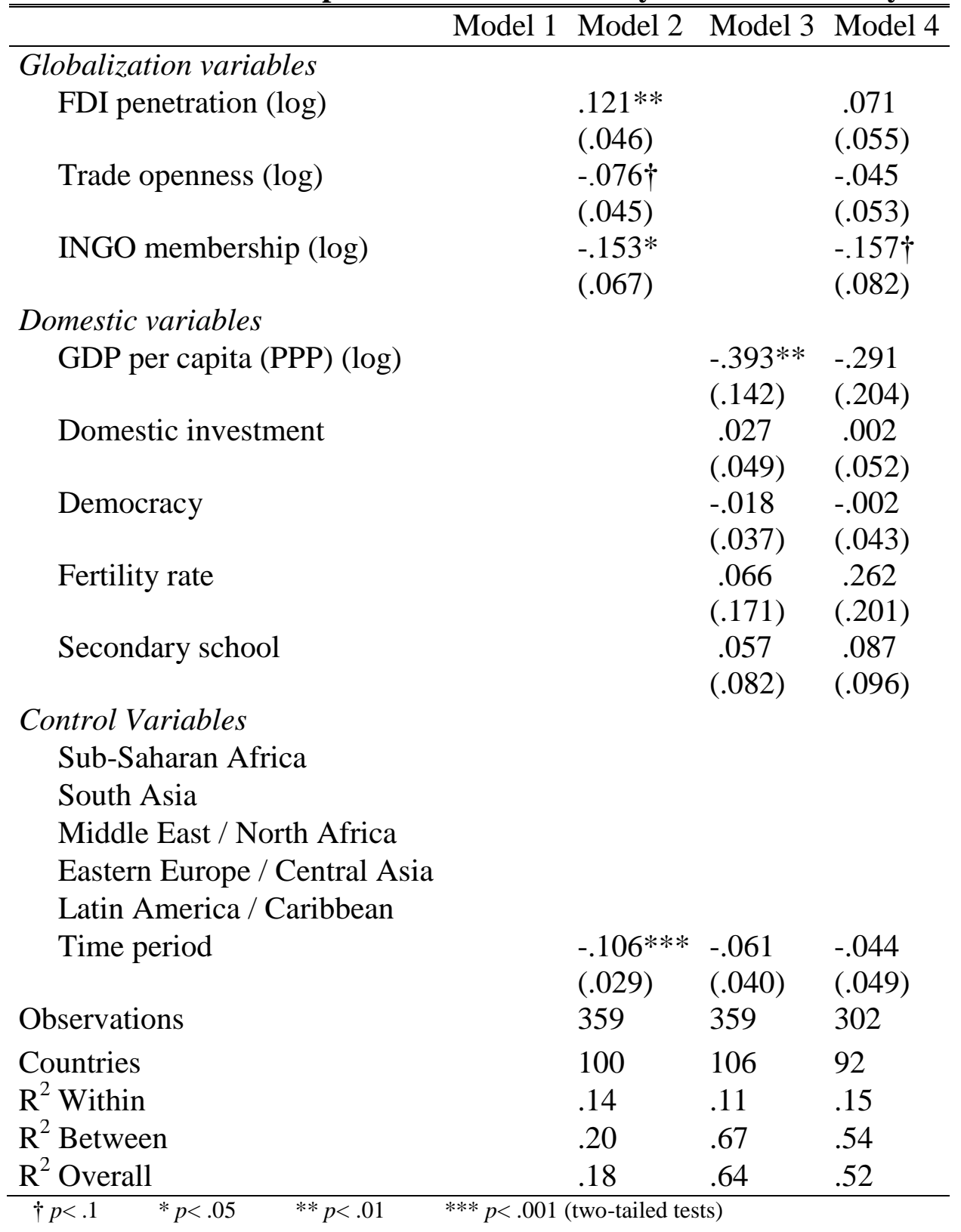

Notes: Six fixed effects regression models (FEMs) examine what globalization and domestic variables are significantly related to poverty at the $\$ 1.25$-a-day level. All models include a first-order autocorrelation correction. Each cell reports the standardized coefficient with the standard error in parentheses. 
Table B2. Relationships with Moderate Poverty at the \$2.50-a-day Level

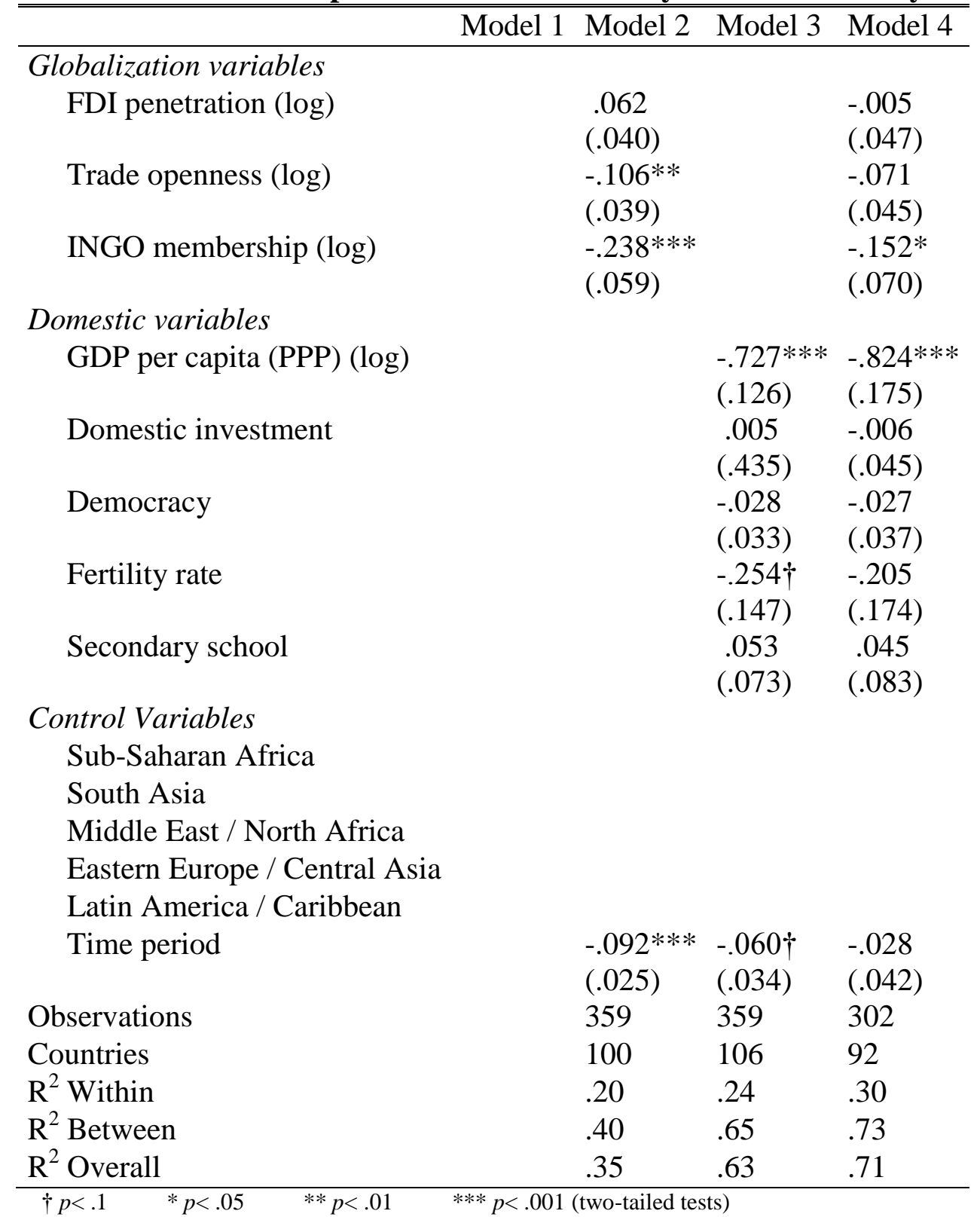

Notes: Six fixed effects regression models (FEMs) examine what global and domestic variables are related to poverty at the \$2.50-a-day level. All models include a first-order autocorrelation correction. Each cell reports the standardized coefficient with the standard error in parentheses 
The Effects of Global Interaction on Poverty 264

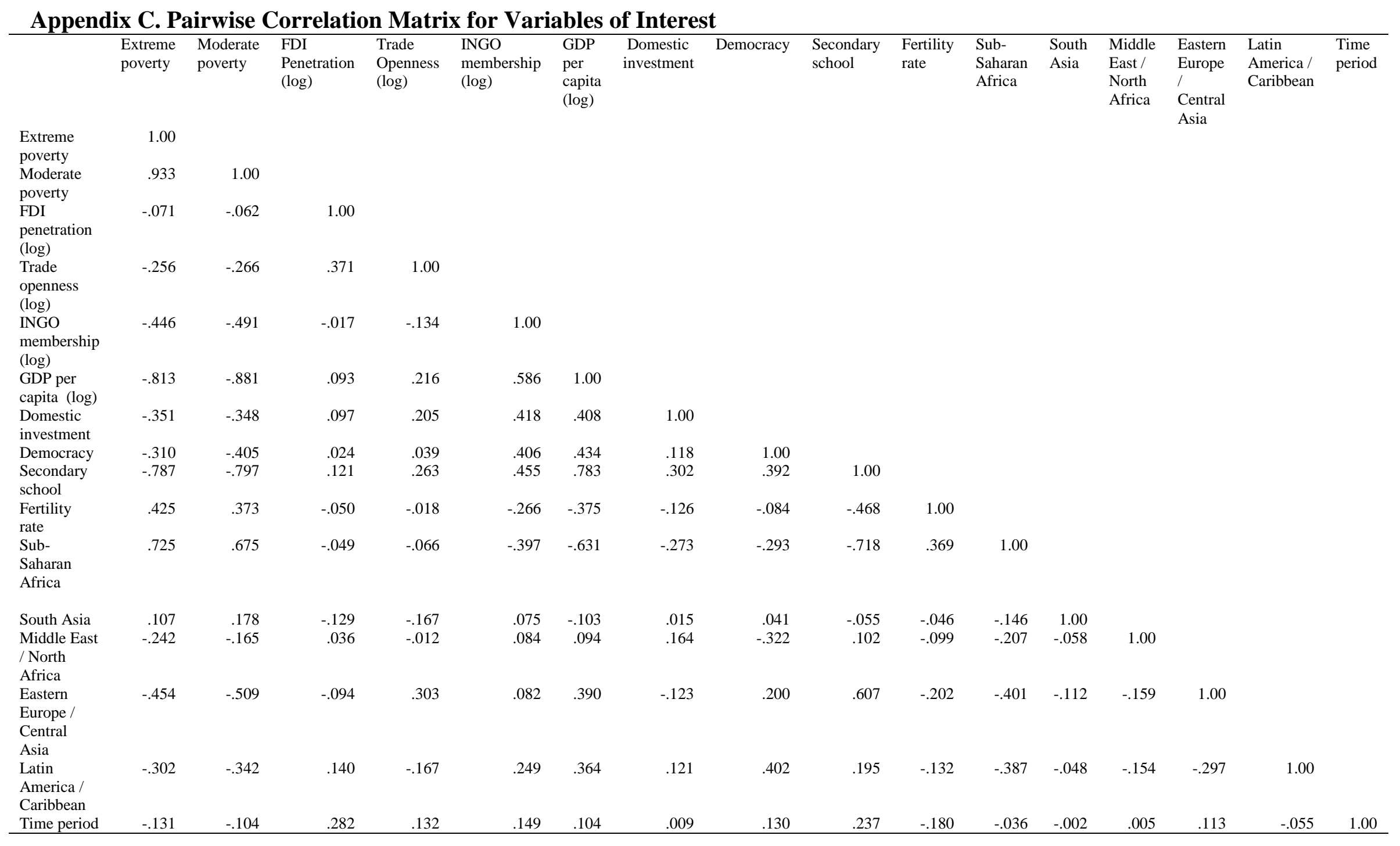


Appendix D. Descriptive Statistics for Unstandardized Variables of Interest

\begin{tabular}{lrrrrr}
\hline \hline Variable & N & Mean & Std. Dev. & Min & Max \\
\hline Extreme poverty & 570 & 28.04 & 26.44 & 0.00 & 88.70 \\
Moderate poverty & 570 & 50.87 & 32.19 & 0.00 & 97.92 \\
FDI (log) & 536 & -1.89 & 1.20 & -5.58 & 1.24 \\
Trade openness (log) & 499 & -.41 & .60 & -2.88 & .97 \\
INGOs (log) & 550 & 6.08 & .83 & -2.77 & 8.59 \\
GDP per capita (log) & 569 & 7.91 & 1.01 & 5.06 & 10.02 \\
Domestic investment (log) & 553 & 27.00 & 27.07 & .72 & 202.12 \\
Democratization & 551 & 2.48 & 5.92 & -10.00 & 10.00 \\
Fertility rate (log) & 570 & 3.75 & 1.76 & 1.10 & 7.81 \\
Secondary school & 494 & 55.74 & 29.57 & 5.18 & 106.75 \\
Sub-Saharan Africa & 570 & .35 & .48 & 0.00 & 1.00 \\
South Asia & 570 & .05 & .22 & 0.00 & 1.00 \\
Middle East / North Africa & 570 & .06 & .24 & 0.00 & 1.00 \\
Eastern Europe / Central Asia & 570 & .24 & .42 & 0.00 & 1.00 \\
Latin America / Caribbean & 570 & .21 & .41 & 0.00 & 1.00 \\
Time & 570 & 3.00 & 1.42 & 1.00 & 5.00 \\
\hline
\end{tabular}

